\begin{tabular}{|c|c|c|c|}
\hline Article Info & RESEARCH ARTICLE & ARAŞTIRMA MAKALESİ & \\
\hline Title of Article & \multicolumn{2}{|c|}{$\begin{array}{l}\text { Investigation of Adequacy of Soke } \\
\text { (Avdin) city Active Open-Green } \\
\text { Spaces }\end{array}$} & \\
\hline $\begin{array}{l}\text { Corresponding } \\
\text { Author }\end{array}$ & \multicolumn{2}{|c|}{$\begin{array}{l}\text { Hamide KÖŞE } \\
\text { Aydın Adnan Menderes Üniversitesi, Fen Bilimleri Enstitüsü, Peyzaj Mimarlığı Anabilim } \\
\text { Dalı,2011600104@stu.adu.edu.tr }\end{array}$} & \\
\hline $\begin{array}{l}\text { Received Date } \\
\text { Accepted Date }\end{array}$ & \multicolumn{2}{|l|}{$\begin{array}{l}10.03 .2021 \\
04.05 .2021 \\
\end{array}$} & \\
\hline DOI Number & \multicolumn{2}{|l|}{ https://doi.org/10.35674/kent.894731 } & \\
\hline Author / Authors & $\begin{array}{l}\text { Hamide KÖŞE } \\
\text { Barış KARA }\end{array}$ & $\begin{array}{l}\text { ORCID: 0000-0001-7022-8957 } \\
\text { ORCID: 0000-0002-5670-8636 }\end{array}$ & \\
\hline How to Cite & \multicolumn{2}{|c|}{$\begin{array}{l}\text { KÖŞE, H. ve KARA, B. (2021). Söke (Aydın) Kenti Aktif Açık-Yeşil Alanlarının } \\
\text { Yeterliliğinin İncelenmesi, Kent Akademisi, Volume, 14, Issue 2, Pages, 374-388. }\end{array}$} & $\begin{array}{l}\text { Kent Akademisi } \\
\text { Urban Academy }\end{array}$ \\
\hline
\end{tabular}

\title{
Söke (Aydın) Kenti Aktif Açık-Yeşil Alanlarının Yeterliliğinin İncelenmesi
}

Hamide KÖŞE ${ }^{1}$

Barış KARA $^{2}$

\begin{abstract}
:
Urban open-green spaces are areas that bring natural life into the city, allow the inhabitants to breathe and have a positive physical and psychological impact. Determining the distribution and size of the open-green spaces in the city will contribute significantly to the planning of the open-green spaces in developing cities. Within the research, the numerical and spatial distribution of active open-green spaces in Soke city (Aydin) according to neighborhoods and the size of active open-green spaces per person were examined. 62 active open-green spaces have been identified in the city of Soke. The active open-green area per person has been found in the Kemalpaşa neighborhood with a maximum of 2.82 square meters and at least 0.56 square meters in Fevzipaşa neighborhood. By combining the date of 8 neighborhoods, the existence of active open-green spaces of the city was analyzed. The active open-green area per person in the city has been determined as 1.82 square meters. It has been revealed that the 10 square meter/person active open-green area defined in the "zoning Law No.3194" is not provided in the neighborhoods of Soke and the whole city. As a result of the study, the active open-green spaces in the master development plan were calculated and found to be 13.41 square meters. According to the regulation, it was determined that it would meet the active open-green area per person.
\end{abstract}

KEY WORDS: Healthy city, active open-green space, adequacy, standart, Söke

\footnotetext{
${ }^{1}$ Aydın Adnan Menderes Üniversitesi, Fen Bilimleri Enstitüsü, Peyzaj Mimarlığı Anabilim Dalı, 2011600104@stu.adu.edu.tr

${ }^{2}$ Aydın Adnan Menderes Üniversitesi, Ziraat Fakültesi, Peyzaj Mimarlığı Bölümü, Peyzaj Planlama Anabilim Dalı, bkara@adu.edu.tr.
} 
ÖZ

Kentsel açık-yeşil alanlar, kente doğal yaşamı getiren, sakinlerin nefes almasını sağlayan, olumlu fiziksel ve psikolojik etkiye sahip alanlardır. Kentlerdeki açık-yeşil alanların dağılımının ve büyüklüğünün belirlenmesi, gelişmekte olan şehirlerdeki açık-yeşil alanların planlanmasına önemli katkı sağlayacaktır. Araştırma kapsamında Söke kentindeki (Aydın) aktif açık-yeşil alanların mahallelere göre sayısal ve mekânsal dağılımı ve kişi başına düşen aktif açık-yeşil alan büyüklükleri incelenmiştir. Söke kentinde 62 adet aktif açık-yeşil alan tespit edilmiştir. Kemalpaşa mahallesinde $2,82 \mathrm{~m}^{2}$ ile en fazla aktif açık-yeşil alan bulunurken, Fevzipaşa mahallesinde $0,56 \mathrm{~m}^{2}$ ile en az kişi başı aktif açık-yeşil alan bulunmuştur. 8 mahallenin aktif açık-yeşil alanları esas alınarak kentin aktif açık-yeşil alan varlığı analiz edilmiştir. Kentte kişi başı aktif açık-yeşil alan 1,82 $\mathrm{m}^{2}$ olarak belirlenmiştir. 3194 sayılı İmar Kanunu'nda tanımlanan $10 \mathrm{~m}^{2} / \mathrm{kişi}$ aktif açık-yeşil alanın Söke mahallelerinde ve tüm kentte sağlanmadığı ortaya çıkmıştır. Araştırma sonucunda imar planında yer alan aktif açık-yeşil alanlar hesaplanmış ve kentte kişi başı $13,41 \mathrm{~m}^{2}$ olarak bulunmuştur. $\mathrm{Bu}$ değer ile Söke kentinin Yönetmeliğe göre kişi başı aktif açık-yeşil alanı karşılayacağı belirlenmiştir.

ANAHTAR KELIMELER: Sağliklı kent, aktif açık-yeşil alan, yeterlilik, standart, Söke

\section{"Söke (Aydın) Kenti Aktif Açık-Yeşil Alanlarının Yeterliliğinin İncelenmesi”}

\section{GíRiș:}

Kentler, insanların doğal alanlar üzerinde kurdukları barınma alanlarıdır. Fiziksel ve ruhsal sağlıklarına katkılarından dolayı insanlar doğadan ayrı düşünülemez. Bu nedenle kentler planlanırken doğal sistemin kent içerisine taşınması gerekmektedir. Bu da kentsel açık-yeşil alan varlığı ile sağlanabilmektedir.

Kentlerde yoğun tempoda yaşayan insanların öncelikli ihtiyaçlarını karşılayan açık-yeşil alanların aşırı nüfus ve yoğun beton yapıların artışı nedeniyle tahrip edilmesi sonucu insanlar stresini topluma yansıtmakta ve mutsuz bir toplum görüntüsü oluşmaktadır (Albayrak, 2006; Yazıcı ve Ünsal, 2019). Doğadan tamamen kopmuş, açık-yeşil alanlara sahip olmayan kentlerde yaşayan insanlar, barındıkları bu ortamlardan fiziksel ve ruhsal açıdan olumsuz etkilenmektedir. İnsanların beton yığınlarından kısa bir sürede olsa kurtuldukları, stresini attıkları, kendileri ile beraber kaldıkları ortamlar olan açık-yeşil alanların iyileştirilmesi ve yeterliliğinin yönetmelikteki standartlara göre sağlanması ile giderilebilecektir (Aytaş, 2017; Yazıcı ve Ünsal, 2019).

Kentler geçmişten günümüze, insanların ekonomik, sosyal, kültürel özelliklerini ve birbirleri ile olan etkileşimini yansıtmaktadır. Bu yansımalar mimari yapıları ve açık-yeşil alanları şekillendirmede etkilidir. Yapılaşmanın ve açıkyeşil alanların kent içerisinde dengeli bir şekilde dağılması yaşam koşullarının iyileşmesinde önemli rol oynamaktadır (Gül ve Küçük, 2001).

Gelişmiş ülkelerde açık-yeşil alanların nitelik ve nicelikleri, medeniyetin ve yaşam kalitesinin bir göstergesi olarak kabul edilmekte ve gelişmişliğin ve toplum refahının bir göstergesi olarak değerlendirilmektedir. Bu kapsamda pek çok gelişmişülke, insanların zihinsel ve fiziksel ihtiyaçlarını göz önünde bulundurarak insan yaşamı için uygun kent mekânı ve ekolojisini planlama/oluşturma çabasına yönelmektedir (Gül ve Küçük, 2001; Yazıcı ve Gülgün Aslan, 2017).

Pamay (1978) ve Gold (1980)'e göre açık alanlar, insanların yaşamlarını sürdürdüğü kapalı mekânların dışında kalan ve bu alanlarla bütünlük sağlayan açık yüzeyler ve kent çeperinde fiziksel sınırlar oluşturarak, kentlerin doğal kimliklerinin ve peyzaj özelliklerinin sürdürülmesini sağlayan, doğal olarak bulunan veya insan eliyle şekillenmiş arazilerdir. Yeşil alanlar ise; kent içi ve kent çevresinde olan koruma (toplum sağlığı), rekreasyon gibi fonksiyonları olan orman, koru, park alanları, refüjler, mezarlıklar, bahçeler gibi canlı (ağaç, ağaççık, çalı, yer örtücü, çayır ve çim alanlar) ve cansız (yollar, havuzlar, oturma elemanları) öğeleri barındıran işlevsel ve estetik olarak çok amaçlı planlanan ve tasarlanan alanlardır (Kuter, 2007).

Toplum bilimci Geray, açık-yeşil alanları; endüstrileşme sonucunda kentlerde iş olanaklarının artması ile doğru orantılı olarak nüfus yoğunluğunun arttığı, insanların kent yaşamı içerisinde doğadan koptuğu ve doğaya zarar verdiği süreçte çeşitli rekreasyon ihtiyaçlarına cevap veren, doğaya yakınlaşmasını ve doğayı kullanmasını sağlayan alanlar olarak tanımlamaktadır (Durmuş, 1997). Kentsel açık-yeşil alanlar, insanların fiziksel aktivitelerini arttırmaya ve ruh sağlığını iyileştirmeye odaklanan yaşam alanlarıdır (Brown vd., 2014). Kentsel açık-yeşil alanlar ekolojik işlevlerinin yanı sıra 
sosyal kaynaşmayı sağlar, toplumsal gelişmeyi körükler, ekonomik amaç ve aktiviteleri destekler, insan sağlığının iyileşmesine yardımcı olur (Etli, 2002).

Açık-yeşil alanlar kullanım biçimlerine göre; kentlerde yaşayanların doğrudan yararlanabilmesi için planlanmış, üzerinde aktivite gerçekleştirilen aktif açık-yeşil alanlar (kent ve mahalle parkı, çocuk bahçesi ve oyun alanları) ve insanların doğrudan ya da dolaylı bir şekilde yararlanabileceği, üzerinde aktivite yapılamayan pasif açık-yeşil alanlar (orman alanları, ağaçlandırma alanları, çalılıklar, kamu ya da özel mülkiyete ait bahçeler, fuar, panayır ve festival alanları, mezarlık) olarak sınıflandırılmaktadır (Koç, 2019).

Açık-yeşil alan standartı, kişi başına açık-yeşil alan büyüklüğü olarak ifade edilmektedir. Açık-yeşil alan toplamlarının nüfusa bölünmesi ile kişi başına açık-yeşil alan büyüklügü hesaplanmaktadır. 3194 sayılı İmar Kanunu'nun 29030 Sayılı Mekânsal Planlar Yapım Yönetmeliği'nde açık-yeşil alan, "açık spor tesisi, park, çocuk bahçesi, oyun alanı vb. alanlar" olarak tanımlanmaktadır. Aynı yönetmeliğe göre belediye ve mücavir alan sınırları içinde açık-yeşil alan büyüklüğü 10 $\mathrm{m}^{2} /$ kişi olarak belirlenmiştir.

“Kronik Hastalıklar Risk Faktörleri Araştırması”na göre Türkiye genelinde kadınların \%87’sinin, erkeklerin \%77'sinin yeterli ölçüde fiziksel aktivite yapmadığı belirlenmiştir. Fiziksel aktiviteye zaman ayırmanın kalp hastalığı, diyabet, kanser, felç, hipertansiyon ve depresyon riskini azalttığı belirtilmektedir (T.C. Sağlı Bakanlı̆̆ı, 2011). Kent içerisinde fiziksel aktivite için açık-yeşil alanlar önemli rol oynamaktadır (Romagosa, 2018).

Türkiye nüfusunun 1927 yılında \%24,2'sinin, 2014 yılında \%91,8'inin (Kiziroğlu, 2017), 2020 yılında da \%93'ünün kentlerde yaşadığı görülmektedir (TÜIK, 2020). Kentlerde yaşanan hızlı nüfus artışı, giderek artan yapılaşma kentlerin doğadan koparak beton yığınlarına dönüşmesine ve açık-yeşil alanların yetersiz kalmasına neden olmakta ve açık-yeşil alanların ekolojik, ekonomik, fiziksel ve toplumsal işlevlerini yerine getirmesini engellemektedir (Albayrak, 2006; Çay ve Karakaya Aytin, 2020). Bu nedenle de kentlerimizin 3194 Sayılı İmar Kanunu'nun 29030 Sayılı Mekânsal Planlar Yapım Yönetmeliği'nde belirtilen standarta göre kişi başına açık-yeşil alan büyüklüğüne uygunluğu değerlendirilmeli, iyileştirilmeleri yönünde öneriler geliştirilmelidir.

Araştırmanın amacı, Söke (Aydın) kentinin, mahalle ve kent ölçeğinde kişi başına açık-yeşil alan (parklar, çocuk oyun alanları ve spor alanları) büyüklüğünü ve aktif açık-yeşil alan yeterliliğini nazım imar planından yararlanarak saptamak ve kentin gelişim sürecinde aktif açık-yeşil alanların yeterliliğinin sağlanmasına yönelik öneriler sunmaktır.

\section{MATERYAL VE YÖNTEM:}

Araştırma alanı olarak seçilen Söke kenti $37^{\circ} 45^{\prime}$ Kuzey enlemi ile $27^{\circ} 24^{\prime}$ ' Doğu boylamı arasında yer almaktadır. Aydın'a 54 km, Didim'e 56 km, Kuşadası'na 23 km, İzmir'e 120 km uzaklıktadır. Söke kent merkezinin yüzölçümü 19.4 km²'dir. Söke kent merkezi 2019 y1lı toplam nüfusu 79195'dir (TÜiK, 2020).

Araştırmanın ana materyalini, Söke kentindeki 8 mahallede (Atatürk Mahallesi, Konak Mahallesi, Yenicami Mahallesi, Çeltikçi Mahallesi, Cumhuriyet Mahallesi, Fevzipaşa Mahallesi, Yenikent Mahallesi, Kemalpaşa Mahallesi) yer alan aktif açık-yeşil alanlar oluşmaktadır (Şekil 1).

Araştırmanın yardımcı materyalleri; kentsel açık-yeşil alanlarla ilgili yazılı ve görsel literatür, 1/5.000 ölçekli Söke kenti Nazım İmar Planı, nüfus verileri, araştırma alanı fotoğrafları, Google Earth, ArcMap 10.5, AutoCAD 2019 ve Adobe Photoshop 2019 yazılımları oluşturmaktadır. 


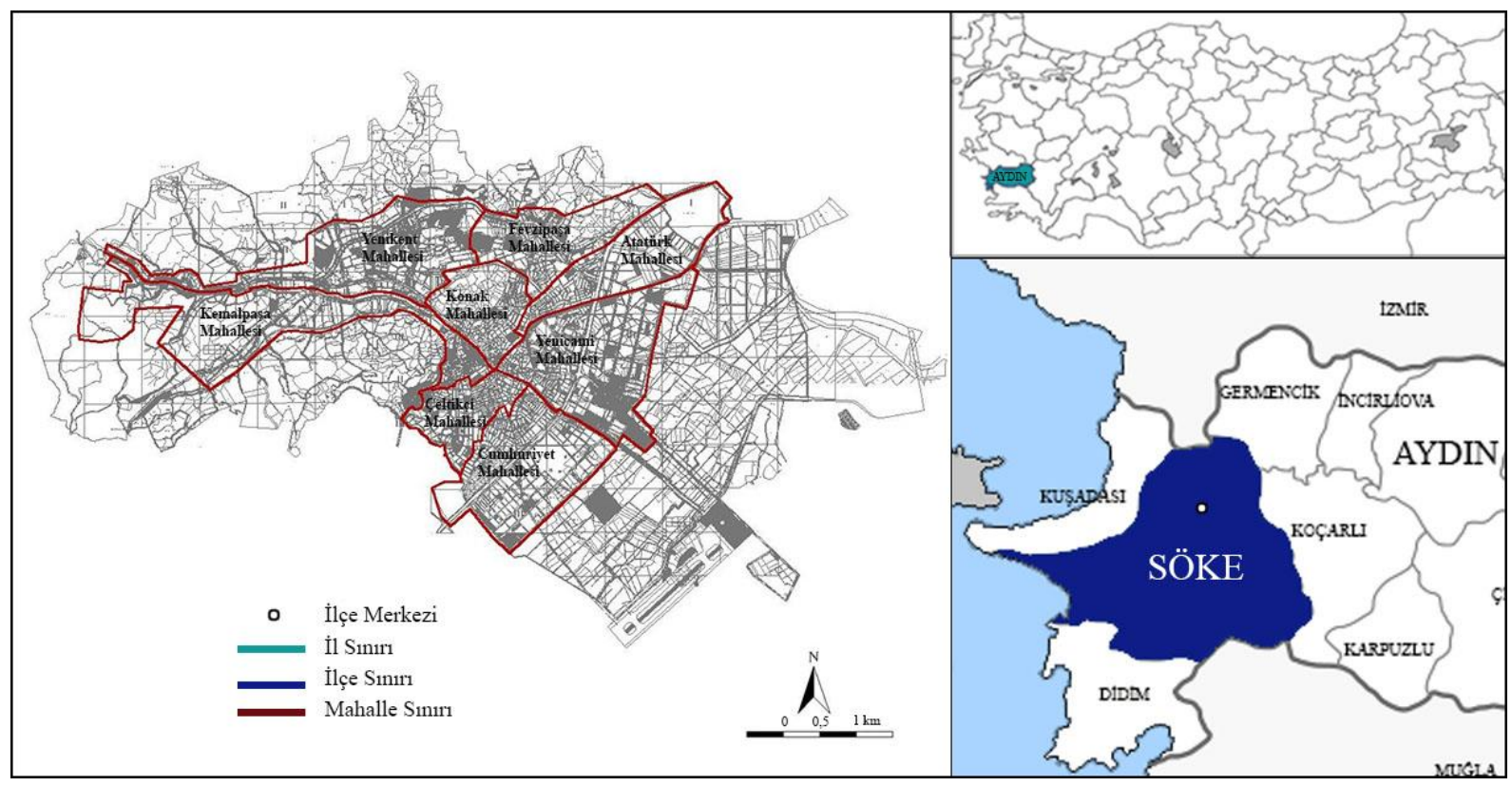

Şekil 1. Araştırma Alanı

Araştırma yöntemi beş aşamadan oluşmaktadır (Şekil 2). Söke kentindeki 8 mahallenin mevcut aktif açık-yeşil alanları 1/5000 ölçekli Nazım İmar Planı, Google Earth programı kullanılarak, alanda yapılan gözlemler ve çekilen fotoğraflarla belirlenmiştir. Aktif açık-yeşil alanlar; parklar, çocuk oyun alanları ve spor alanları olmak üzere üç grupta sınıflandırılmıştır.

AutoCAD 2019 yazılımında, mahallelerin yüz ölçümleri, aktif açık-yeşil alanların büyüklükleri, aktif açık-yeşil alanların mahalle yüz ölçümlerine oranları, mahallere ve kente göre kişi başına aktif açık-yeşil alan büyüklükleri tespit edilmiştir. Adobe Photoshop 2019 ve ArcMap 10.5 yazılımları kullanılarak haritalar oluşturulmuştur. 3194 Sayılı İmar Kanunu'nun 29030 Sayılı Mekânsal Planlar Yapım Yönetmeliği'ne göre de mahalle ve kent ölçeğinde kişi başına açıkyeşil alan büyüklükleri değerlendirilmiştir.

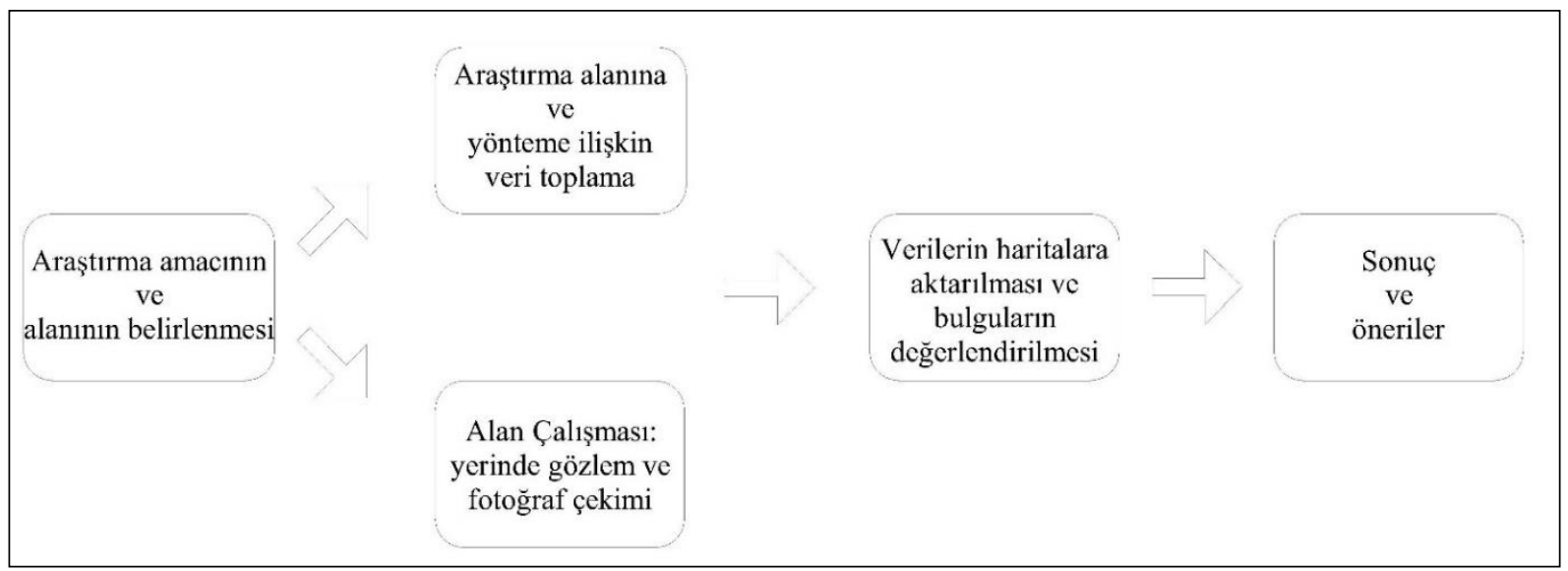

Şekil 2. Yöntem Akış Şeması

\section{BULGULAR VE TARTIŞMA:}

Söke kentinde Yenicami Mahallesi 15.200 kişi ile nüfusu en fazla olan mahalle iken, Kemalpaşa Mahallesi 4.016 kişi ile nüfusu en az olan mahalledir. Yüzölçümü en büyük olan mahalle $3,7 \mathrm{~km}^{2}$ ile Kemalpaşa Mahallesi iken, yüzölçümü en küçük olan mahalle 1,1 km² ile Çeltikçi Mahallesidir. En fazla sayıda aktif açık-yeşil alanın olduğu mahalle 15 adet 
ile Yenicami Mahallesi iken, en az sayıda aktif açı-yeşil alanın olduğu mahalle 2 adet ile Kemalpaşa Mahallesidir. Çeltikçi Mahallesi $24.844 \mathrm{~m}^{2}$ ile en fazla aktif açık-yeşil alana sahip mahalle iken, Fevzipaşa Mahallesi $3.852 \mathrm{~m}^{2}$ ile en az aktif açık-yeşil alana sahip mahalledir. En fazla nüfus yoğunluğu $\left(11.871 \mathrm{kişi} / \mathrm{km}^{2}\right)$ Çeltikçi Mahallesinde iken, en az nüfus yoğunluğu $\left(1.085 \mathrm{kişi} / \mathrm{km}^{2}\right)$ Kemalpaşa Mahallesindedir. Aktif açı-yeşil alan/mahalle yüzölçümü oranının en yüksek olduğu $(0,023)$ mahalle Çeltikçi Mahallesi, en düşük olduğu $(0,002)$ mahalle Fevzipaşa Mahallesidir. Kemalpaşa Mahallesi 2,82 $\mathrm{m}^{2}$ ile en fazla kişi başına aktif açık-yeşil alan olan mahalle iken, Fevzipaşa Mahallesi 0,56 $\mathrm{m}^{2}$ ile en az kişi başına aktif açık-yeşil alan olan mahalledir. Yenikent Mahallesi $396.806 \mathrm{~m}^{2}$ ile İmar Planında en fazla açık-yeşil alan önerisinin yapıldığı mahalle iken, Atatürk Mahallesi $15.134 \mathrm{~m}^{2}$ ile en az açık-yeşil alan önerisinin yapıldığı mahalledir. En fazla toplam aktif açık-yeşil alan $418.397 \mathrm{~m}^{2}$ ile Yenikent Mahallesinde bulunurken, en az toplam aktif açık-yeşil alan $39.114 \mathrm{~m}^{2}$ ile Atatürk Mahallesinde bulunmaktadır. Nazım İmar Planındaki öneri açık-yeşil alanların uygulanması durumunda en fazla kişi başına aktif açık-yeşil alanın olduğu $\left(43,79 \mathrm{~m}^{2}\right)$ mahalle Yenikent Mahallesi iken, en az kişi başına aktif açık-yeşil alanın olduğu $\left(3,46 \mathrm{~m}^{2}\right)$ mahalle Atatürk Mahallesidir (Tablo 1).

Tablo 1. Söke Kenti Mahalleleri Nüfus Ve Alansal Özellikleri

\begin{tabular}{|c|c|c|c|c|c|c|c|c|c|c|}
\hline $\begin{array}{l}\vec{z} \\
\stackrel{0}{0} \\
\frac{\pi}{\pi} \\
\bar{\pi}\end{array}$ & $\sum_{:}^{\infty}$ & 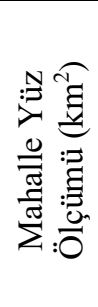 & 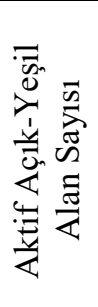 & 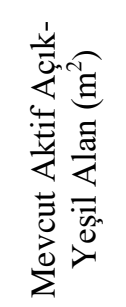 & 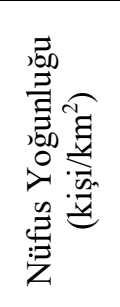 & 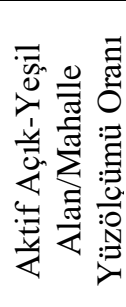 & 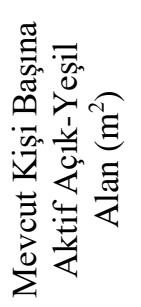 & 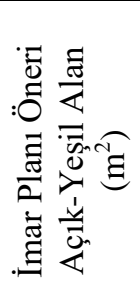 & 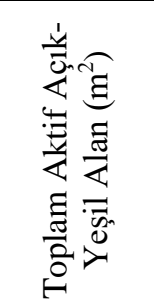 & 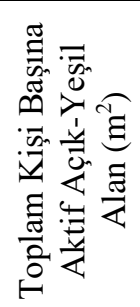 \\
\hline Atatürk & 11.313 & 2,2 & 13 & 23.980 & 5.142 & 0,011 & 2,12 & 15.134 & 39.114 & 3,46 \\
\hline Konak & 11.110 & 1,3 & 5 & 22.317 & 8.546 & 0,017 & 2,01 & 22.411 & 44.728 & 4,03 \\
\hline Yenicami & 15.200 & 3,2 & 15 & 24.416 & 4.750 & 0,008 & 1,61 & 104.958 & 129.374 & 8,51 \\
\hline Çeltikçi & 13.058 & 1,1 & 9 & 24.844 & 11.871 & $\mathbf{0 , 0 2 3}$ & 1,90 & 56.836 & 81.680 & 6,25 \\
\hline Cumhuriyet & 8.071 & 2,9 & 9 & 12.027 & 2.783 & 0,004 & 1,49 & 71.169 & 83.196 & 10,31 \\
\hline Fevzipaşa & 6.872 & 1,8 & 4 & 3.852 & 3.818 & 0,002 & 0,56 & 161.314 & 165.166 & 24,03 \\
\hline Yenikent & 9.555 & 3,1 & 5 & 21.591 & 3.082 & 0,007 & 2,26 & 396.806 & 418.397 & 43,79 \\
\hline Kemalpaşa & 4.016 & 3,7 & 2 & 11.332 & 1.085 & 0,003 & 2,82 & 89.112 & 100.444 & 25,01 \\
\hline TOPLAM & 79.195 & 19,3 & 62 & 144.359 & 4.103 & 0,007 & 1,82 & 917.740 & 1.062 .099 & 13,41 \\
\hline
\end{tabular}

Söke kentinin kuzeydoğusunda yer alan Atatürk Mahallesinde 13 adet aktif açık-yeşil alan bulunmaktadır (Tablo 1-2, Şekil 3). Mahallenin en büyük aktif açık-yeşil alanı $10.135 \mathrm{~m}^{2}$ ile Uğur Mumcu Parkı, en küçük aktif açık-yeşil alanı $113 \mathrm{~m}^{2}$ ile Seven Sokak Parkı'dır (Tablo 2, Şekil 4).

Kentsel yerleşimin merkezinde yer alan Konak Mahallesi 5 adet aktif açık-yeşil alana sahiptir (Tablo 1-2, Şekil 3). Belediye ve Hükümet meydanı mahalle sınırı içerisinde yer almaktadır. Mahalledeki en büyük aktif açık-yeşil alan $14.377 \mathrm{~m}^{2}$ ile Atatürk Parkı, en küçük aktif açık-yeşil alan $172 \mathrm{~m}^{2}$ ile Onur Sokak Çocuk oyun alanıdır (Tablo 2, Şekil $4)$.

Kentin doğusunda yer alan Yenicami Mahallesinde 15 adet aktif açık-yeşil alan yer almaktadır (Tablo 1-2, Şekil 3). Mahallenin en büyük aktif açık-yeşil alanını $6.039 \mathrm{~m}^{2}$ ile 6 Eylül Pakı, en küçük aktif açık-yeşil alanını $371 \mathrm{~m}^{2}$ ile Şehit Mehmet Ali Birlik Parkı oluşturmaktadır (Tablo 2, Şekil 4).

Kentin güneyinde yer alan Çeltikçi Mahallesi 9 adet aktif açık-yeşil alana sahiptir (Tablo 1-2, Şekil 3). Mahalledeki en büyük aktif açık-yeşil alanı $7.309 \mathrm{~m}^{2}$ alan büyüklüğüne sahip Adalet Parkı, en küçük aktif açı-yeşil alanı $387 \mathrm{~m}^{2}$ alan büyüklüğüne sahip Süner Sokak Parkı oluşturmaktadır (Tablo 2, Şekil 4). 
Kentin güneyinde yer alan Cumhuriyet Mahallesinde 9 adet aktif açık-yeşil alan bulunmaktadır (Tablo 1-2, Şekil 3). Mahallenin en büyük aktif açık-yeşil alanı $3.508 \mathrm{~m}^{2}$ ile Şehit Mustafa Korkmaz Parkı, en küçük aktif açık-yeşil alanı $375 \mathrm{~m}^{2}$ ile Şehit Ercan Özgün Parkıdır (Tablo 2, Şekil 4).

Kentin kuzeyinde yer alan Fevzipaşa Mahallesinde 4 adet aktif açık-yeşil alan yer almaktadır (Tablo 1-2, Şekil 3). Mahalledeki en büyük aktif açık-yeşil alan $2.098 \mathrm{~m}^{2}$ ile Şehit Mustafa Özdemir Parkı, en küçük aktif açı-yeşil alanı $344 \mathrm{~m}^{2}$ ile Zımba Sokak Parkıdır (Tablo 2, Şekil 4).

Kentin kuzeybatısında yer alan Yenikent Mahallesi 5 adet aktif açık-yeşil alana sahiptir (Tablo 1-2, Şekil 3). Mahallenin en büyük aktif açık-yeşil alanını $9.764 \mathrm{~m}^{2}$ alan büyüklügü̈ ile Harikalar Diyarı Parkı, en küçük aktif açık-yeşil alanını $1.581 \mathrm{~m}^{2}$ alan büyüklüğü ile Devlet Hastanesi Yanı Parkı oluşturmaktadır (Tablo 2, Şekil 4).

Kentin batısında ve güneybatısında yer alan Kemalpaşa Mahallesinde 2 adet aktif açık-yeşil alan yer almaktadır (Tablo 1-2, Şekil 3). Mahallenin en büyük aktif açık-yeşil alanı $10.936 \mathrm{~m}^{2}$ ile Kemalpaşa Parkı, en küçük aktif açık-yeşil alanı $396 \mathrm{~m}^{2}$ ile Atalay Sokak Parkıdır (Tablo 2, Şekil 4).

Söke kentinde 62 adet aktif açık-yeşil alan bulunmaktadır (Tablo 1, Şekil 5). Kentin en büyük aktif açık-yeşil alanı $14.377 \mathrm{~m}^{2}$ ile Atatürk Parkı, en küçük aktif açık-yeşil alanı $113 \mathrm{~m}^{2}$ ile Seven Sokak Parkı'dır (Tablo 2, Şekil 4).

Tablo 2. Söke Kenti Mahallelere Göre Aktif Açık-Yeşil Alanlar ve Büyüklükleri

\begin{tabular}{|c|c|c|c|c|c|c|}
\hline Mahalle & $\begin{array}{c}\text { Aktif } \\
\text { Açık-Yeşil } \\
\text { Alan No }\end{array}$ & $\begin{array}{c}\text { Aktif Açık-Yeşil } \\
\text { Alan }\end{array}$ & $\begin{array}{l}\text { Aktif Açık- } \\
\text { Yeşil Alan } \\
\left(\mathrm{m}^{2}\right)\end{array}$ & $\begin{array}{l}\text { Aktif Açı- } \\
\text { Yeşil Alan } \\
\text { No }\end{array}$ & $\begin{array}{c}\text { Aktif Açık-Yeşil } \\
\text { Alan }\end{array}$ & $\begin{array}{c}\text { Aktif } \\
\text { Açık- } \\
\text { Yeşil } \\
\text { Alan }\left(\mathrm{m}^{2}\right) \\
\end{array}$ \\
\hline \multirow{7}{*}{ Atatürk } & 1 & $\begin{array}{l}\text { Şehit Remzi İlboğa } \\
\text { Parkı }\end{array}$ & 342 & 8 & $\begin{array}{l}\text { Şehit Süleyman } \\
\text { Teke Parkı }\end{array}$ & 1.355 \\
\hline & 2 & $\begin{array}{l}\text { Umut Vural Engelli } \\
\text { Park1 }\end{array}$ & 1.395 & 9 & \multirow{2}{*}{$\begin{array}{l}\text { Ŭgur Mumcu } \\
\text { Parkı } \\
\text { Şehit Arif Kaplan } \\
\text { Park1 }\end{array}$} & 10.135 \\
\hline & 3 & Seven Sokak Parkı & 113 & 10 & & 1.326 \\
\hline & 4 & $\begin{array}{l}\text { Şehit Murat } \\
\text { Yıldızgünlü Parkı }\end{array}$ & 1.733 & 11 & Hasan Çakır Parkı & 727 \\
\hline & 5 & $\begin{array}{l}\text { Çankırı-Ekrem K. } \\
\text { Sok. Parkı }\end{array}$ & 361 & 12 & $\begin{array}{l}\text { Şehit Hakkı Uyar } \\
\text { Park1 }\end{array}$ & 3.670 \\
\hline & 6 & $\begin{array}{l}\text { Şehit Sevinç Çelik } \\
\text { Park1 }\end{array}$ & 638 & 13 & Trafik Eğitim Parkı & 1.592 \\
\hline & 7 & $\begin{array}{l}\text { Hanımeli Sokak } \\
\text { Park1 }\end{array}$ & 593 & & & \\
\hline \multirow{3}{*}{ Konak } & 1 & Atatürk Parkı & 14.377 & 4 & \multirow{3}{*}{$\begin{array}{l}\text { Onur Sokak } \\
\text { Çocuk Oyun } \\
\text { Alanı } \\
\text { Vali Recep } \\
\text { Yazıcığlu Parkı }\end{array}$} & 172 \\
\hline & 2 & Belediye Meydanı & 3.481 & 5 & & 1.192 \\
\hline & 3 & Hükümet Meydanı & 3.095 & & & \\
\hline \multirow{5}{*}{ Yenicami } & 1 & $\begin{array}{l}\text { Şehit Celal İsen } \\
\text { Park1 }\end{array}$ & 1.129 & 9 & 6 Eylül Parkı & 6.039 \\
\hline & 2 & $\begin{array}{l}\text { Şehit Mehmet Ali } \\
\text { Birlik Parkı }\end{array}$ & 371 & 10 & İnci Sokak Parkı & 568 \\
\hline & 3 & $\begin{array}{l}\text { Şehit Mehmet Kaya } \\
\text { Çergin Parkı }\end{array}$ & 1.807 & 11 & Tan Sokak Parkı & 803 \\
\hline & 4 & $\begin{array}{l}\text { Şehit Hüseyin Süngü } \\
\text { Parkı }\end{array}$ & 2.118 & 12 & Çiftlik Sokak Parkı & 408 \\
\hline & 5 & $\begin{array}{l}\text { Şen Irmak Sokak } \\
\text { Parkı }\end{array}$ & 415 & 13 & Nene Torun Parkı & 1.630 \\
\hline
\end{tabular}




\begin{tabular}{|c|c|c|c|c|c|c|}
\hline & 6 & \multirow{3}{*}{$\begin{array}{l}\text { Şehit Ömer Özoğul } \\
\text { Park1 } \\
\text { Şehit Mehmet } \\
\text { Edremitli Park1 } \\
\text { Eren Yıldırım Sok. } \\
\text { Park1 }\end{array}$} & \multirow{2}{*}{$\begin{array}{l}2.782 \\
1.740\end{array}$} & \multirow{2}{*}{$\begin{array}{l}14 \\
15\end{array}$} & \multirow{3}{*}{$\begin{array}{l}\text { TuraTürkmen-Ural } \\
\text { Sok. Parkı } \\
\text { Şehit Tahsin } \\
\text { Yıldırım Parkı }\end{array}$} & \multirow{3}{*}{$\begin{array}{r}768 \\
2.523\end{array}$} \\
\hline & 7 & & & & & \\
\hline & 8 & & 1.315 & & & \\
\hline \multirow{5}{*}{ Çeltikçi } & 1 & Adalet Parkı & 7.309 & 6 & $\begin{array}{l}\text { Zekai Avcıoğlu } \\
\text { Sokak Çocuk Oyun } \\
\text { Alanı }\end{array}$ & 452 \\
\hline & 2 & Mini Sokak Park1 & 585 & 7 & Güngör Pura Parkı & 3.741 \\
\hline & 3 & $\begin{array}{l}\text { Halime'nin Deresi } \\
\text { Park1 }\end{array}$ & 1.382 & 8 & Barış Manço Parkı & 7.266 \\
\hline & 4 & Süner Sokak Parkı & 387 & 9 & $\begin{array}{l}\text { Şehit Şerif } \\
\text { Çalışkan }\end{array}$ & 1.548 \\
\hline & 5 & $\begin{array}{l}\text { Şehit Tufan Aydın } \\
\text { Parkı }\end{array}$ & 2.174 & & & \\
\hline \multirow{5}{*}{ Cumhuriyet } & 1 & $\begin{array}{l}\text { Şehit Mustafa } \\
\text { Korkmaz Parkı }\end{array}$ & 3.508 & 6 & $\begin{array}{l}\text { Şehit Ercan } \\
\text { Özgün Parkı }\end{array}$ & 375 \\
\hline & 2 & $\begin{array}{l}\text { Şehit Ferdi Bolat } \\
\text { Park1 }\end{array}$ & 2.335 & 7 & $\begin{array}{l}\text { Şehit Kâmil Çırpan } \\
\text { Parkı }\end{array}$ & 1.139 \\
\hline & 3 & $\begin{array}{l}\text { Sera Yolu Çocuk } \\
\text { Oyun Alanı }\end{array}$ & 536 & 8 & $\begin{array}{l}\text { Şehit Serkan } \\
\text { Altınkaynak Parkı }\end{array}$ & 826 \\
\hline & 4 & $\begin{array}{l}\text { Sevgili Öğretmenim } \\
\text { Park1 }\end{array}$ & 2.155 & 9 & $\begin{array}{l}\text { Sanayi Çıraklık } \\
\text { Eğitim Parkı }\end{array}$ & 662 \\
\hline & 5 & Subaşı Sokak Park1 & 491 & & & \\
\hline \multirow{2}{*}{ Fevzipaşa } & 1 & Zımba Sokak Parkı & 344 & 3 & $\begin{array}{l}\text { Şehit Mustafa } \\
\text { Özdemir Parkı }\end{array}$ & 2.098 \\
\hline & 2 & Muhtarlık Önü Parkı & 697 & 4 & $\begin{array}{l}\text { Şehit Zeki Esmer } \\
\text { Park1 }\end{array}$ & 713 \\
\hline \multirow{3}{*}{ Yenikent } & 1 & Tarık Akan Parkı & 6.127 & 4 & $\begin{array}{l}\text { Harikalar Diyarı } \\
\text { Parkı }\end{array}$ & 9.764 \\
\hline & 2 & Zeytin Dalı Parkı & 2.291 & 5 & $\begin{array}{l}\text { Devlet Hastanesi } \\
\text { Yanı Park }\end{array}$ & 1.581 \\
\hline & 3 & $\begin{array}{l}\text { Zeytin D. P. Yürüyüş } \\
\text { Yolu }\end{array}$ & 1.828 & & & \\
\hline Kemalpaşa & 1 & Kemalpaşa Parkı & 10.936 & 2 & $\begin{array}{l}\text { Atalay Sokak } \\
\text { Parkı }\end{array}$ & 396 \\
\hline
\end{tabular}

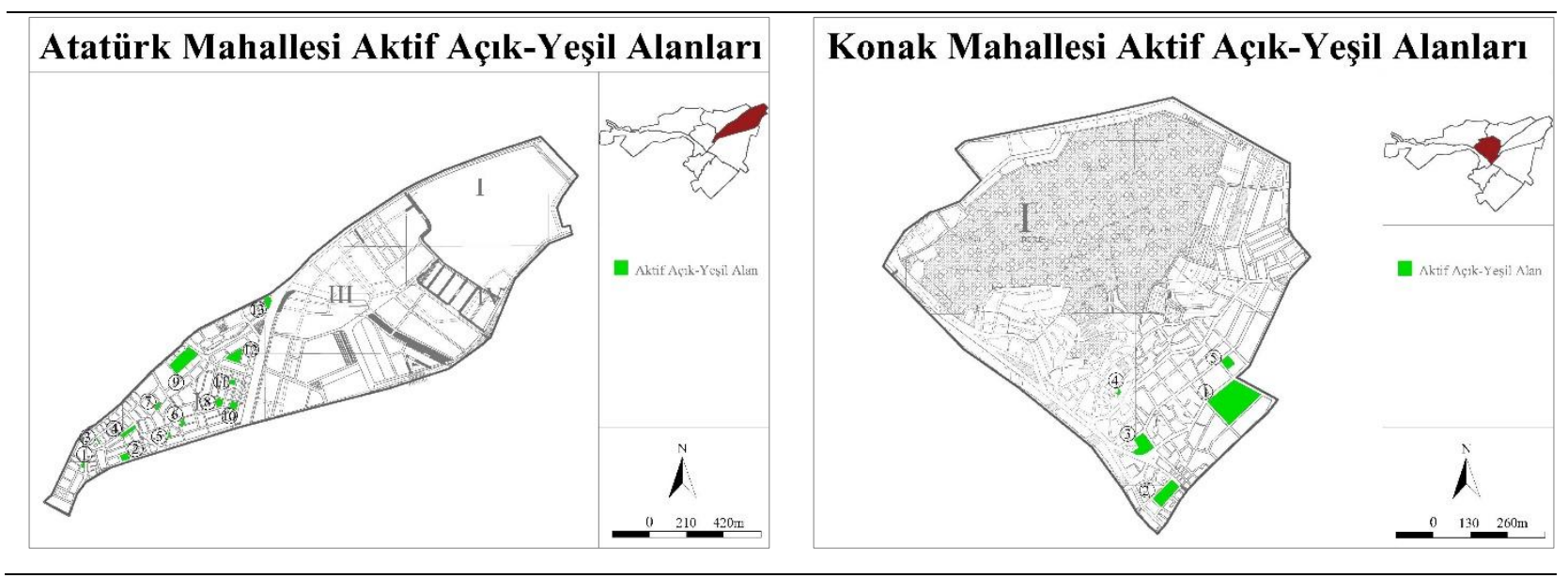




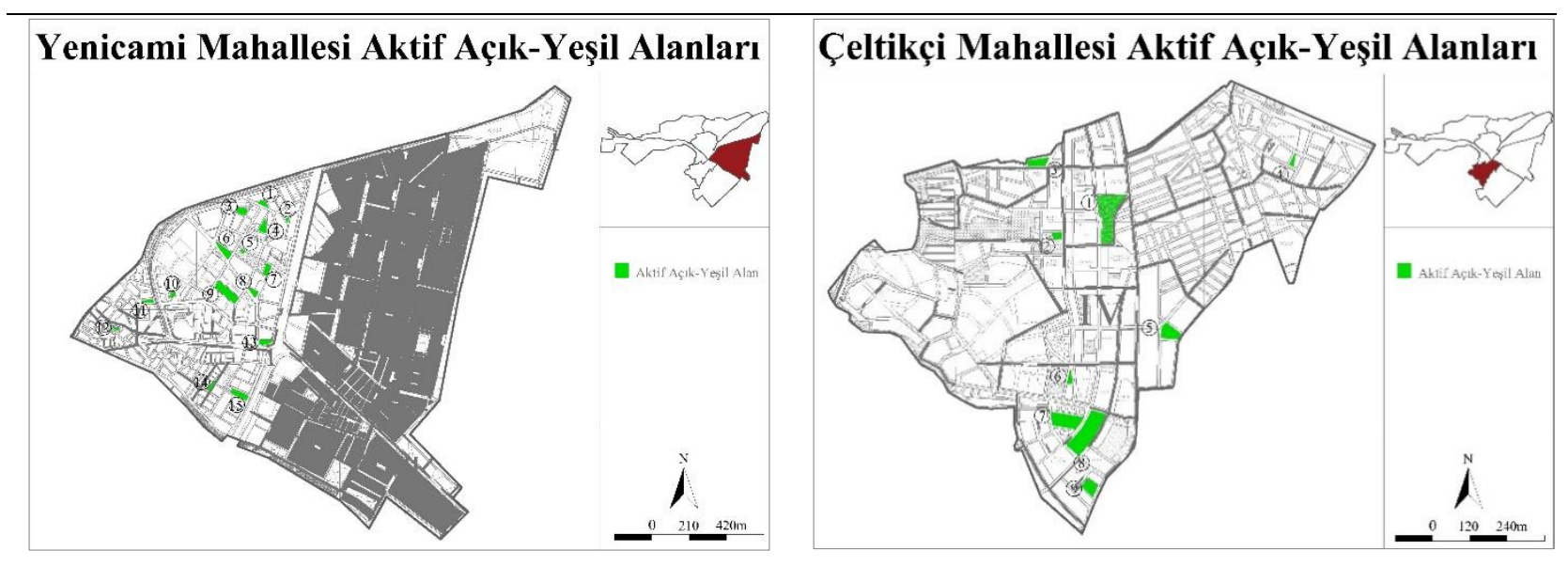

\section{Cumhuriyet Mahallesi Aktif Açık-Yeșil Alanları}
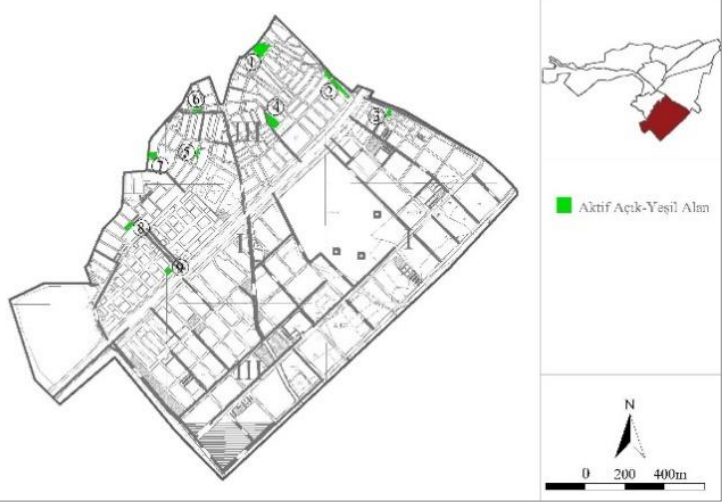

\section{Fevzipaşa Mahallesi Aktif Açık-Yeșil Alanları}

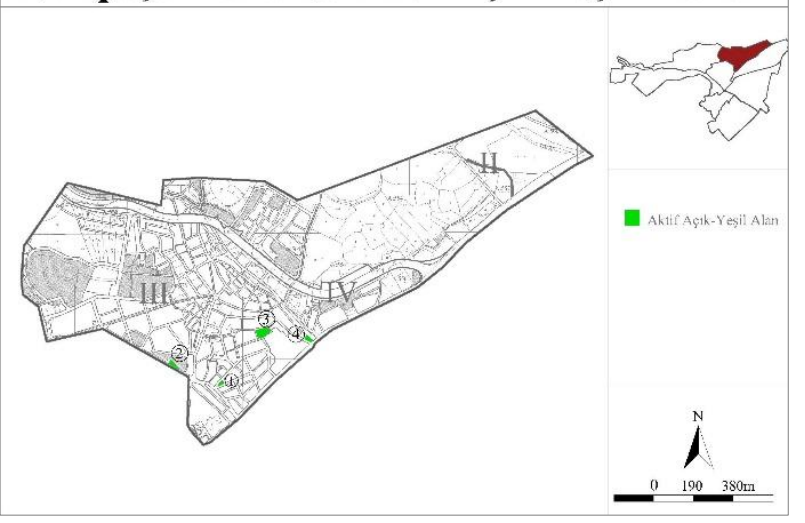

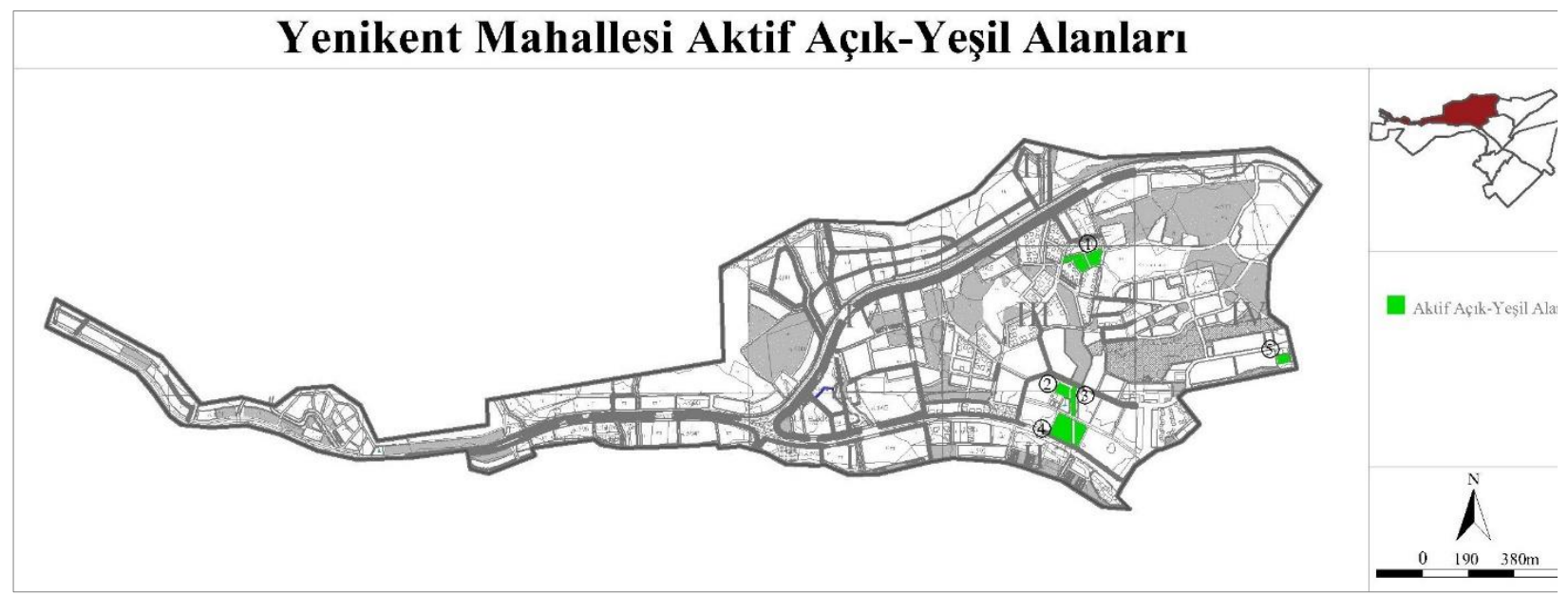




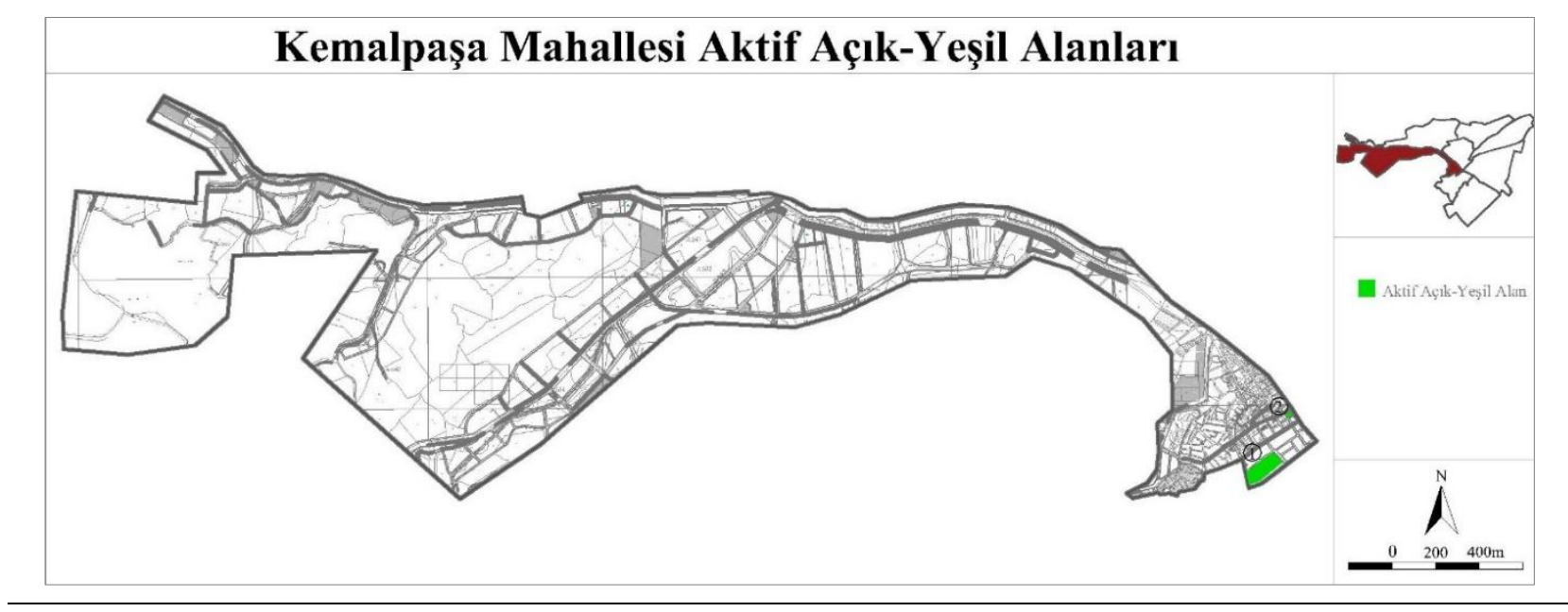

Şekil 3. Söke Kenti Mahallelere Göre Açık-Yeşil Alanlar

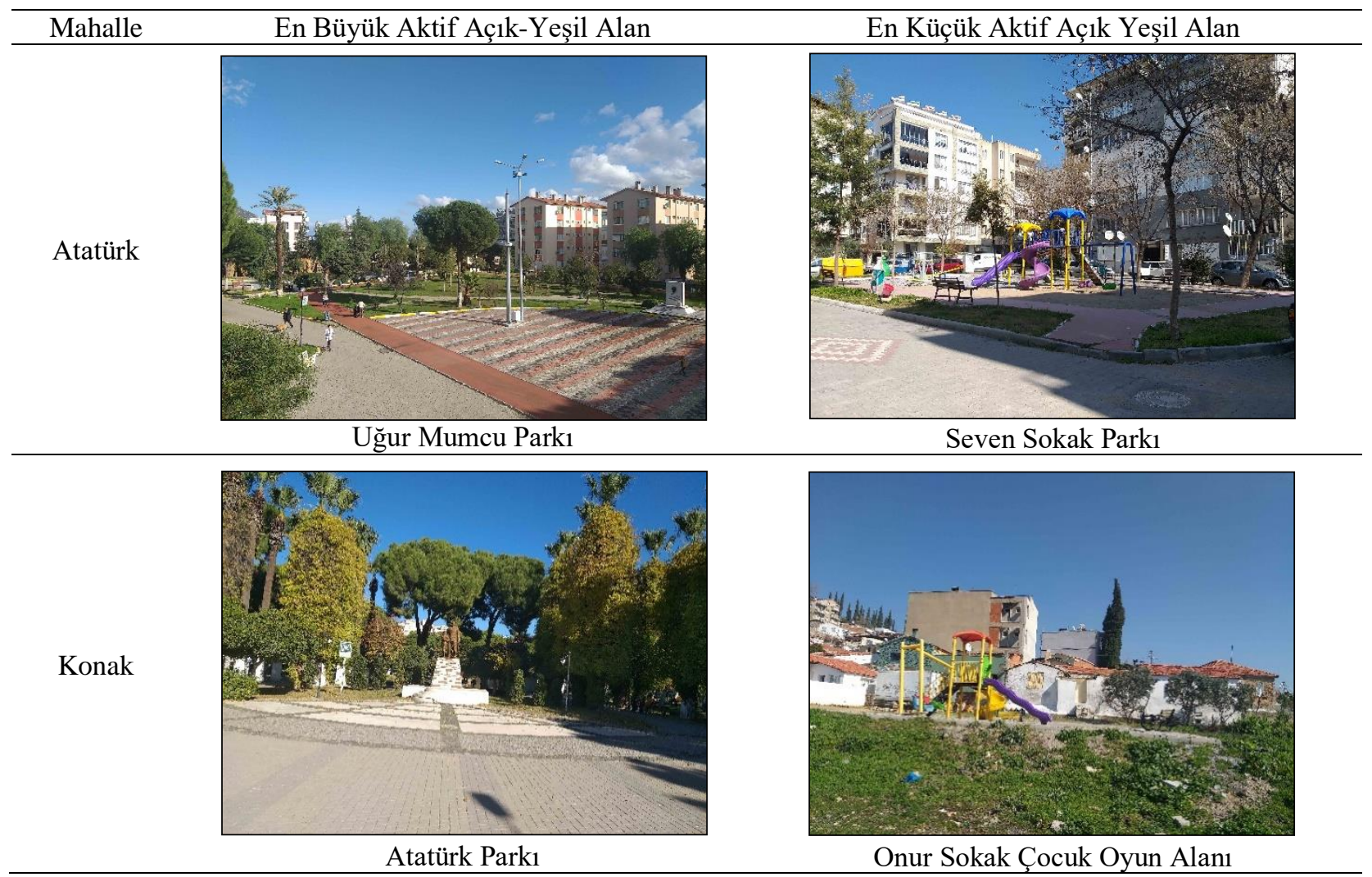




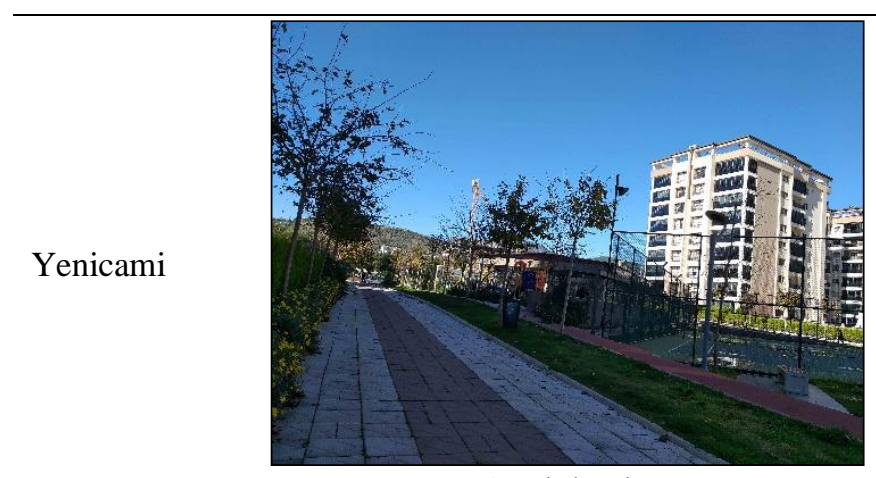

6 Eylül Pakı

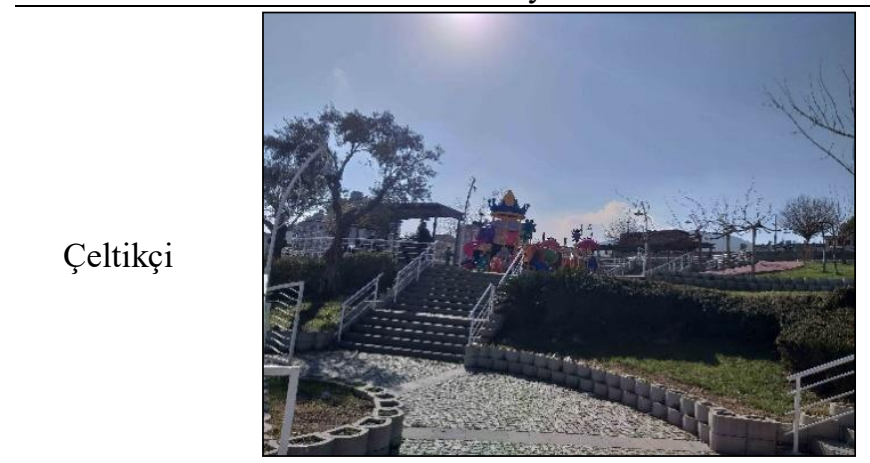

Adalet Park1

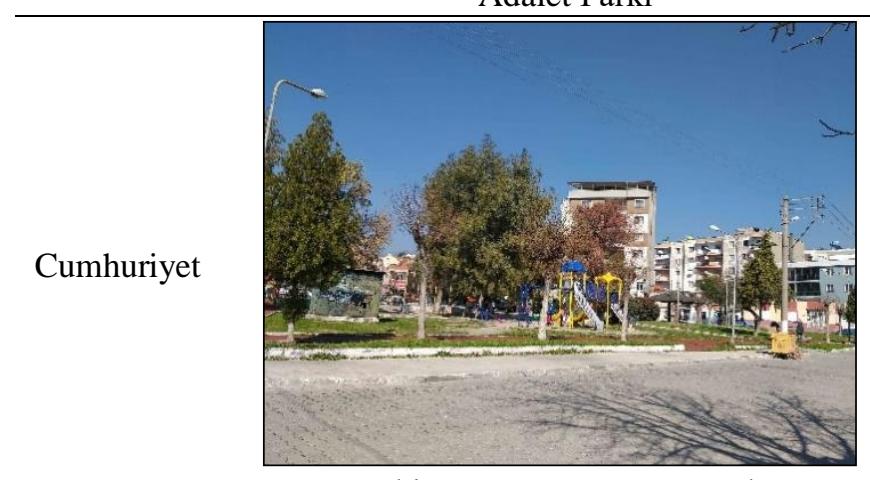

Şehit Mustafa Korkmaz Parkı

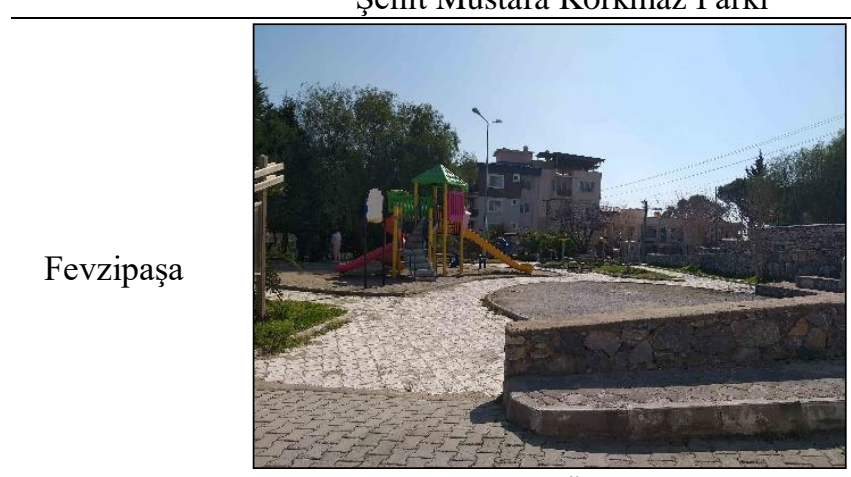

Şehit Mustafa Özdemir Parkı

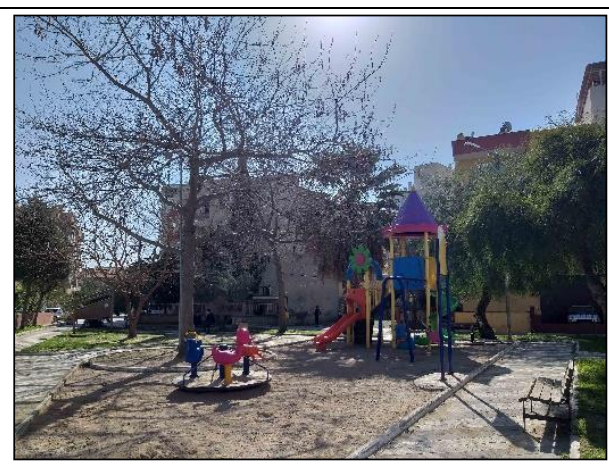

Şehit Mehmet Ali Birlik Parkı

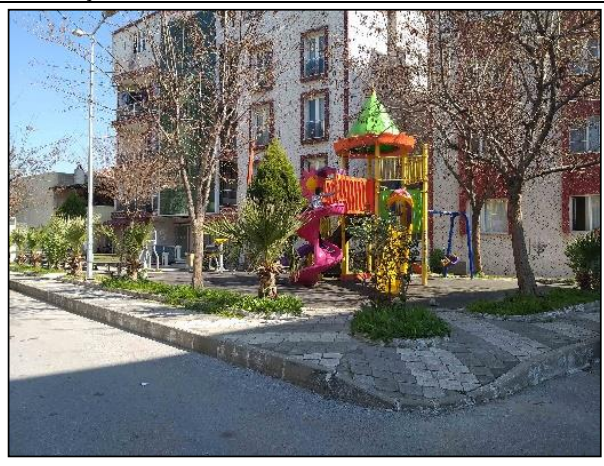

Süner Sokak Parkı

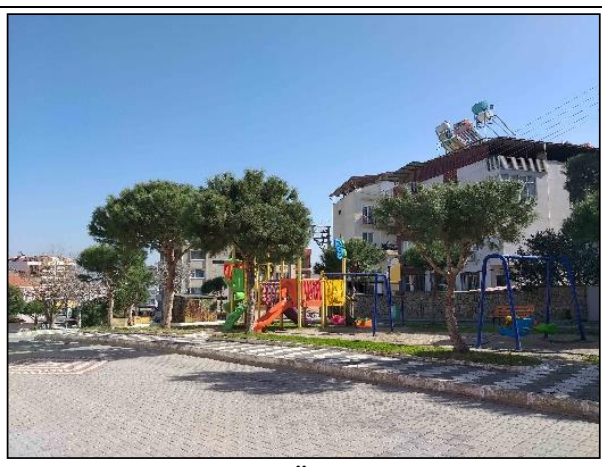

Şehit Ercan Özgün Park1

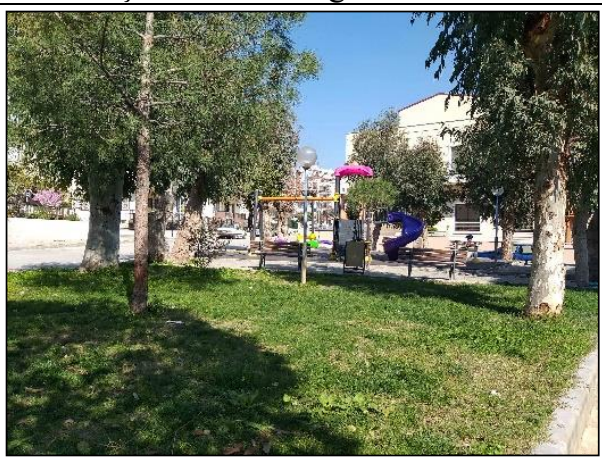

Zımba Sokak Parkı 


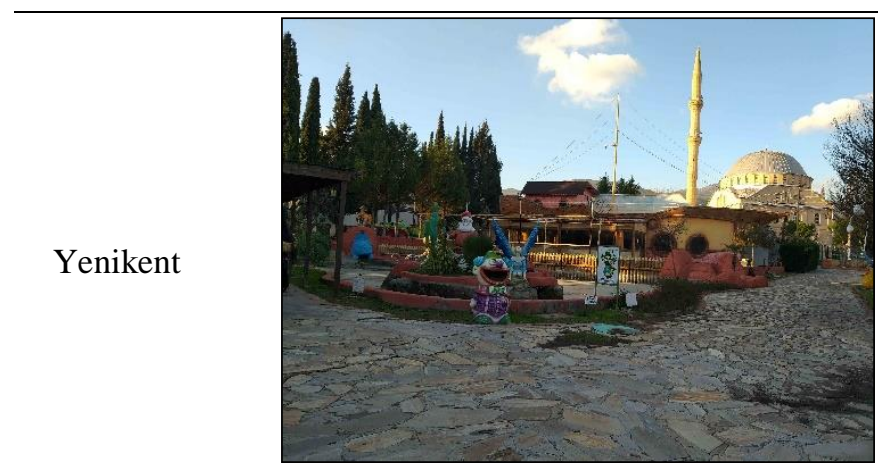

Harikalar Diyarı Parkı

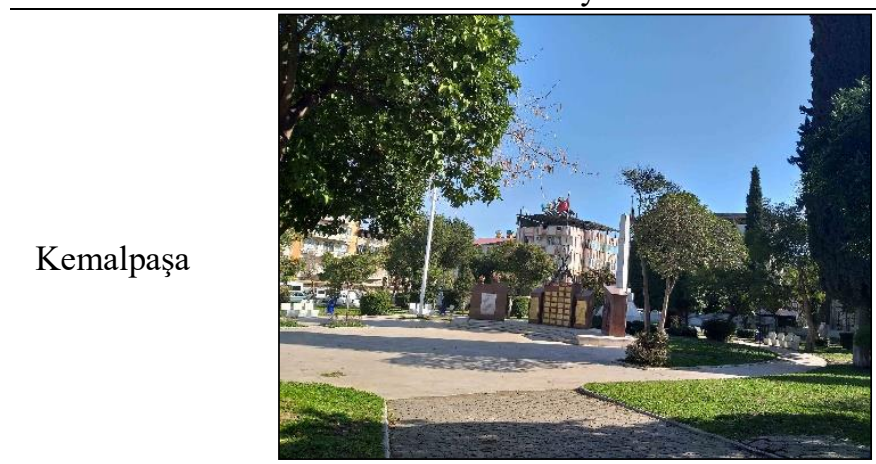

Kemalpaşa Parkı

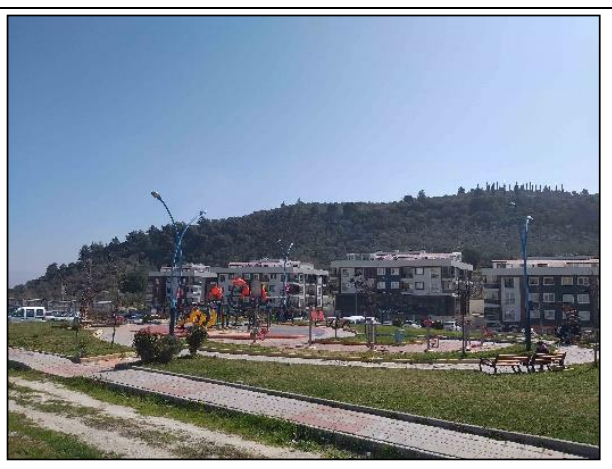

Devlet Hastanesi Yanı Park

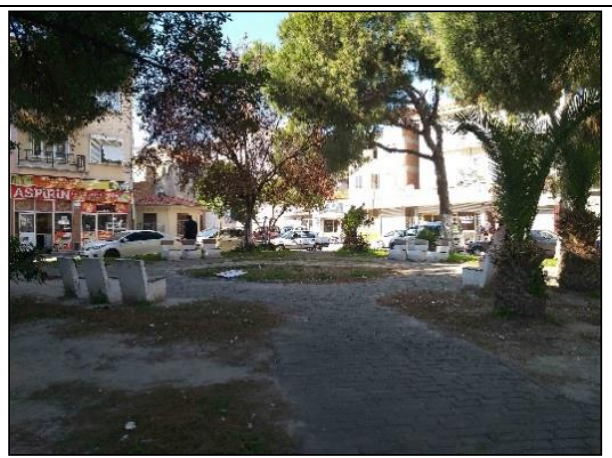

Atalay Sokak Parkı

Şekil 4. Söke Kenti Mahallelere Göre En Büyük ve En Küçük Aktif Açık-Yeşil Alanlar

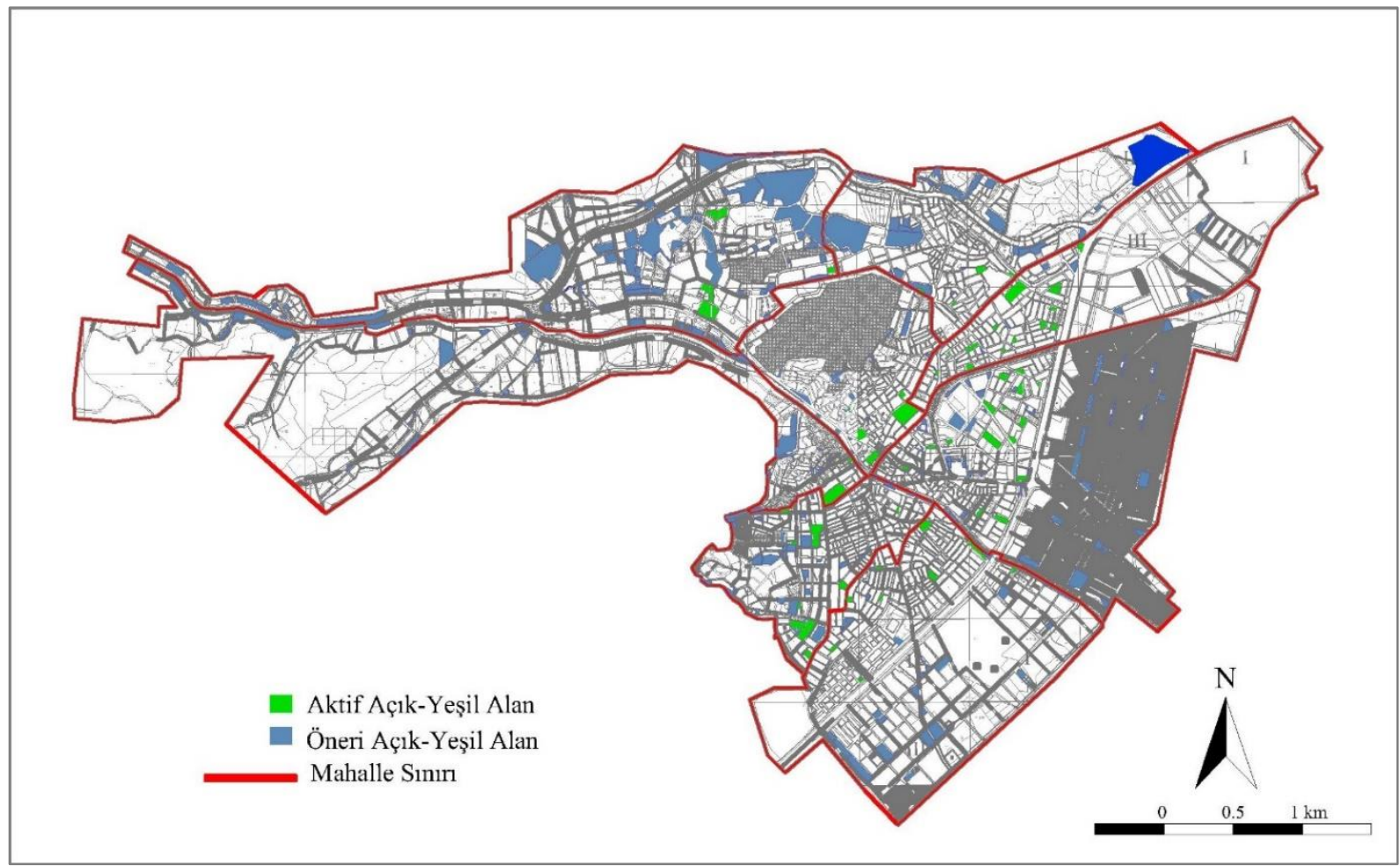

Şekil 5. Söke Kenti Aktif Açık-Yeşil Alanları 


\section{SONUÇ VE ÖNERILER:}

Atatürk Mahallesinin kuzey doğu bölümünde yerleșim alanı bulunmadığı için mevcut aktif açık-yeşil alanlar düzenli dağılım göstermektedir. Atatürk Mahallesi aktif açık-yeşil alanları kişi başına 2,12 $\mathrm{m}^{2}$ ile 3194 Sayılı İmar Kanunu'nun 29030 Sayılı Mekânsal Planlar Yapım Yönetmeliği’ne göre kişi başına $10 \mathrm{~m}^{2}$ standartını sağlamamaktadır. Mahallede yönetmelikte belirtilen kişi başına $10 \mathrm{~m}^{2}$ aktif açık-yeşil alanın olabilmesi için $89.150 \mathrm{~m}^{2}$ ilave aktif açık alana gereksinim duyulmaktadır. İmar planında öneri açık-yeşil alanların toplamı $15.134 \mathrm{~m}^{2}$ dir. İmar planındaki öneri açıkyeşil alanın uygulanması durumunda mahallenin kişi başına aktif açık-yeşil alan büyüklüğü 3,46 $\mathrm{m}^{2}$ olacaktır (Tablo 1).

Yücesu vd. (2017), Kırklareli kentindeki araştırmasında aktif açık-yeşil alanların mahallerde düzenli dağılmadığını tespit etmiştir. Aktif açık-yeşil alanların düzenli dağılmaması yeşil alanlara erişimi sınırlandırmaktadır. Konak mahallesinde de aktif açık yeşil alanlar düzenli dağılmadığı için erişimi zorlaşmaktadır. Mahalle halkının aktif açık yeşil alanlardan aynı oranda faydalanması sağlanamamaktadır. Mahalledeki aktif açık-yeşil alanlar belediye ve hükümet meydanının burada olmasından dolayı yoğun olarak kullanılmaktadır. Mahallede heyelan bölgesinin açık-yeşil alan olarak kullanılamaması ve sit bölgesi olması mahallede aktif açık-yeşil alanların artırılmasını sınırlandırmaktadır. Mahallede 2,01 $\mathrm{m}^{2}$ aktif açık-yeşil alan ile kişi başına $10 \mathrm{~m}^{2}$ aktif açık-yeşil alan standartı karşılanmamaktadır. Konak Mahallesinde yönetmelikte belirtilen kişi başına $10 \mathrm{~m}^{2}$ aktif açık-yeşil alanın olabilmesi için $88.783 \mathrm{~m}^{2}$ ilave aktif açık alana gereksinim duyulmaktadır. İmar planında öneri açık-yeşil alan toplamı $22.411 \mathrm{~m}^{2}$ dir. İmar planında önerilen açıkyeşil alanın uygulanması durumunda mahallede kişi başına aktif açık-yeşil alan büyüklüğü $4,03 \mathrm{~m}^{2}$ olacaktır (Tablo 1).

Yenicami Mahallesindeki parklar alansal olarak küçüktür ve parçalı yapı göstermektedir. Mahallenin doğusunda yapılaşma başlamıştır. Mahallede kişi başına $1,61 \mathrm{~m}^{2}$ aktif açık-yeşil alan ile kişi başına $10 \mathrm{~m}^{2}$ aktif açık-yeşil alan standartı sağlanmamaktadır. Yenicami Mahallesinde yönetmeliğe göre kişi başına $10 \mathrm{~m}^{2}$ aktif açık-yeşil alanın olabilmesi için $127.584 \mathrm{~m}^{2}$ ek aktif açık alana gereksinim duyulmaktadır. İmar planında önerilmiş açık-yeşil alan toplamı $104.958 \mathrm{~m}^{2}$, dir. İmar planındaki öneri açık-yeşil alanın uygulanması durumunda mahalledeki kişi başına aktif açık-yeşil alan büyüklüğü $8,51 \mathrm{~m}^{2}$ olacaktır (Tablo 1).

Çeltikçi Mahallesinde de aktif açık-yeşil alanlar düzenli dağılmamaktadır. Kişi başına $1,90 \mathrm{~m}^{2}$ aktif açık-yeşil alan büyüklügü ile mahallede kişi başına $10 \mathrm{~m}^{2}$ aktif açık-yeşil alan standartı sağlanmamaktadır. Çeltikçi Mahallesinde yönetmelikteki kişi başına $10 \mathrm{~m}^{2}$ aktif açık-yeşil alanın olabilmesi için $105.736 \mathrm{~m}^{2}$ ilave aktif açık alana ihtiyaç duyulmaktadır. İmar planında öneri açık-yeşil alan $56.836 \mathrm{~m}^{2}$ dir. İmar planındaki önerilen açı-yeşil alanın uygulanması durumunda mahallenin kişi başına aktif açık-yeşil alan büyüklüğü $6,25 \mathrm{~m}^{2}$ olacaktır (Tablo 1).

Cumhuriyet Mahallesinde bulunan stadyum sadece maçlarda kullanıldığı için dahil edilmemiştir. Mahallede 1,49 $\mathrm{m}^{2}$ aktif açık-yeşil alan ile kişi başına $10 \mathrm{~m}^{2}$ aktif açık-yeşil alan standartı karşılanmamaktadır. Mahallede yönetmelikte belirtilen kişi başına $10 \mathrm{~m}^{2}$ aktif açık-yeşil alanın olabilmesi için $68.683 \mathrm{~m}^{2}$ ilave aktif açık alana gereksinim duyulmaktadır. İmar planında önerilmiş açık-yeşil alan toplamı $71.169 \mathrm{~m}^{2}$ dir. İmar planındaki öneri açık-yeşil alanın uygulandığında mahallenin kişi başına aktif açık-yeşil alan büyüklüğ̈̈ $10,31 \mathrm{~m}^{2}$ olacak, böylece yönetmelikte belirtilen standart karşılanacaktır.

Fevzipaşa Mahallesinde aktif açık-yeşil alanların mahallenin güneyinde bulunması erişimi zorlaştırmaktadır. 0,56 $\mathrm{m}^{2}$ aktif açık-yeşil alan büyüklüğü ile mahallede kişi başına $10 \mathrm{~m}^{2}$ aktif açık-yeşil alan standartı sağlanmamaktadır. Mahallede yönetmeliğe göre kişi başına $10 \mathrm{~m}^{2}$ aktif açık-yeşil alanın olabilmesi için $64.868 \mathrm{~m}^{2}$ ilave aktif açık alana ihtiyaç vardır. İmar planında önerilen açık-yeşil alan $161.314 \mathrm{~m}^{2}$ dir. İmar planında önerilen açık-yeşil alanın uygulanması durumunda mahalle kişi başına $24,03 \mathrm{~m}^{2}$ aktif açık-yeşil alan büyüklüğü ile yönetmelikte belirtilen standartı sağlayacaktır (Tablo 1).

Yenikent mahallesi gelişmekte olan bir mahalledir. Mahallenin batısı ve kuzeyinde yapılaşma devam etmektedir. Nazım imar planında kentsel büyüme alanı olarak planlanmış ve mahalle sınırı içerisinde geniş açık-yeşil alanlar bırakılmıştır. Mahallede kişi başına 2,26 $\mathrm{m}^{2}$ ile $10 \mathrm{~m}^{2}$ aktif açık-yeşil alan standartı karşılanmamaktadır. Yenikent Mahallesinde yönetmelikteki kişi başına $10 \mathrm{~m}^{2}$ aktif açık-yeşil alanın olabilmesi için $73.959 \mathrm{~m}^{2}$ aktif açık alana gereksinim duyulmaktadır. İmar planında önerilmiş açık-yeşil alan $396.806 \mathrm{~m}^{2}$ 'dir. Tüm mahalleler içinde en büyük açık-yeşil alan önerisinin yapıldığı mahalledir. İmar planındaki önerilen açık-yeşil alanın uygulanması durumunda mahallenin kişi başına aktif açık-yeşil alan büyüklüğü $43,79 \mathrm{~m}^{2}$ olacaktır (Tablo 1). Kişi başına en fazla aktif açık-yeşil alanın sağlandığı mahalledir. 
Aktif açık-yeşil alanların düzenli dağılım göstermediği bir diğer mahalle de Kemalpaşa Mahallesidir. Mahallede sit olduğu için yapılaşma ve kentsel yayılma azdır. Mahallede kişi başına $2,82 \mathrm{~m}^{2}$ aktif açık-yeşil alan ile $10 \mathrm{~m}^{2}$ aktif açıkyeşil alan standartı sağlanmamaktadır. Kemalpaşa Mahallesinde yönetmelikte belirtilen kişi başına $10 \mathrm{~m}^{2}$ aktif açıkyeşil alanın olabilmesi için $28.828 \mathrm{~m}^{2}$ aktif açık alana gereksinim duyulmaktadır. İmar planında önerilmiş açık-yeşil alan $89.112 \mathrm{~m}^{2}$ 'dir. İmar planındaki öneri açık-yeşil alanın uygulanması durumunda mahallenin kişi başına aktif açıkyeşil alan büyüklüğü $25,01 \mathrm{~m}^{2}$ olacaktır (Tablo 1). Bu değer ile yönetmelikte belirtilen standart sağlanmaktadır.

Söke kentinde 8 mahallede açık-yeşil alan bulunmaktadır. Bu sonucun aksine Gül ve Küçük (2001) Isparta kentinde yaptıkları araştırmada açık-yeşil alana sahip olmayan mahalleler olduğunu tespit etmiştir. Kentsel açık-yeşil alanların yeterliliği üzerine yapılan araştırmalarda Keloğlu ve Karabacak (2020) Denizli kentinde 45 mahallenin 6'sında; Yücesu vd. (2017) ise Kırıkkale kentinde 12 mahallenin 3'ünde $10 \mathrm{~m}^{2}$ standartının sağlandığını tespit etmiştir. Söke kentinde ise tüm mahallelerde de bu standart sağlanmamaktadır. Türkiye'de yapılan bazı araştırmalarda da mevcut kişi başına aktif açık-yeşil alan büyüklüklerinin $3 \mathrm{~m}^{2}$ (Gül ve Küçük, 2001), 1,4 $\mathrm{m}^{2}$ (Doygun ve İlter, 2007), $2 \mathrm{~m}^{2}$ (Yavuz ve Eminağaoğlu, 2007), 1,6 m² (Yücesu vd., 2017) ve $4 \mathrm{~m}^{2}$ (Koçan ve İbiş, 2020), bulunmuştur. Bu araştırmaların sonuçları kişi başına aktif açık-yeşil alanların yönetmelikte belirtilen $10 \mathrm{~m}^{2}$ standartını karşılamadığını göstermektedir. Söke kentinde yapılan bu araştırmada da kişi başına aktif açık-yeşil alan 1,82 $\mathrm{m}^{2}$ olarak saptanmıştır. Bulunan bu sonuç diğer araştırma sonuçları ile benzerlik göstermektedir. Söke kentindeki hiçbir mahallede ve kent bütününde 3194 Sayılı İmar Kanunu'nun 29030 Sayılı Mekânsal Planlar Yapım Yönetmeliği'nde belirtilen kişi başına $10 \mathrm{~m}^{2}$ aktif açık-yeşil alan standartı sağlanmamaktadır. Söke kentinde yönetmelikte belirtilen kişi başına $10 \mathrm{~m}^{2}$ aktif açık-yeşil alanın olabilmesi için $647.591 \mathrm{~m}^{2}$ aktif açık alana gereksinim duyulmaktadır. İmar planında öneri açık-yeşil alan toplamı $917.740 \mathrm{~m}^{2}$ 'dir. İmar planındaki önerilen açık-yeşil alanın uygulanması durumunda kentte kişi başına aktif açık-yeşil alan büyüklüğü $13,41 \mathrm{~m}^{2}$ olacaktır (Tablo 1). İmar planında öneri açık-yeşil alanların uygulanması durumunda Söke kentindeki dört mahallede (Cumhuriyet mahallesi, Fevzipaşa mahallesi, Yenikent mahallesi ve Kemalpaşa mahallesi) ve Söke kentinde yönetmelikte belirtilen kişi başına $10 \mathrm{~m}^{2}$ standartı sağlanmaktadır.

Eşbah (2006), Aydın kentinde yaptığı araştırmada açık-yeşil alanların yeterli büyüklükte olmadığını bu durumun bitki ve yaban hayatının gelişmesine olanak sağlamadığını belirtmişsir. Doygun ve İlter (2007), ise açık-yeşil alanların küçük ve çok parçalı olması durumunda aynı anda yararlanacak kişi sayısının yeterli olmayacağını, kent ekolojilerine katkıları bakımından olumsuzluklar oluşturacağını belirtmiştir.

Benzer şekilde Söke kentinde de küçük ve parçalı açık-yeşil alanlar bulunmaktadır. İmar planında önerilen açık-yeşil alanlar içerisinde de bu durum görülmektedir. Menteşe (2019) araştırmasında açık-yeşil alanların düzenli dağılmamasından dolayı aynı oranda erişimin mümkün olmadığı sonucuna ulaşmıştır. Söke kentindeki Atatürk ve Yenicami mahalleleri dışındaki mahallelerde de aynı sorun mevcuttur. Öneri açık-yeşil alanların uygulanması durumunda kentteki aktif açık-yeşil alanların dağılımı daha düzenli ve erişimi daha kolay olacaktır. Keloğlu ve Karabacak (2020), araştırmasında yoğun ve sıkışık yerleşim alanlarının olduğu merkez mahallelerde yeni park alanlarının planlanmasının pek mümkün olmamasından dolayı şehrin yeni gelişen çevre mahallelerine, daha geniş ve daha fazla aktiviteyi barındıran alanların planlanmasını önermektedir. Hilberseimer (1955), yeşil alanların kent için gereksinimini karşılamada nüfusun büyük önem taşıdığını, kentlerde artan nüfusa karşı yeşil alanların yeterli standartı karşılayıp karşılamadığı ve yeşil alanlar planlanırken kent çevresindeki büyümelerde yoğunlaştığı, kent merkezlerinde ve yoğun yapılaşma olan alanlarda imar planlarındaki revizyonlarla öneri yeşil alan standartına ulaşmanın mümkün olmadığı anlatılmıştır (Aksoy vd., 2009). Söke kentinde de aynı durumun mevcut olduğu görülmektedir. Söke kenti imar planı incelendiğinde büyük açık-yeşil alanların Fevzipaşa ve Yenikent Mahallesi gibi gelişim gösteren çevre mahallelerde önerildiği görülmektedir.

Söke kentinde aktif açık-yeşil alan yeterliliğini sağlamak için nazım imar planlarında önerilen açık-yeşil alanlar mahallere göre düzenli dağılacak şekilde planlanmalı, gelişmekte olan mahallelerde kişi başına düşen yeşil alan büyüklükleri hesaplanarak nazım imar planları revize edilmelidir.

\section{Etik Standart ile Uyumluluk}

Çıkar Çatışması: Yazarlar herhangi bir çıkar çatışmasının olmadığını beyan eder.

Etik Kurul İzni: Bu çalışma için etik kurul iznine gerek yoktur.

Finansal Destek: Yoktur. 
Teşekkür: Yoktur.

\section{KAYNAKÇA:}

AKSOY, Y., TURAN, A.Ç. ve ATALAY, H. (2009). İstanbul Fatih İlçesi Yeşil Alan Yeterliliğinin Marmara Depremi Öncesi ve Sonrası Değerleri Kullanılarak İncelenmesi. Uludağ University Journal of The Faculty of Engineering, 14(2):137-150.

ALBAYRAK, B. (2006). Çorum Kenti Mevcut Alan Kullanım Kararları ve Açık-Yeşil Alan Verilerinin Değerlendirilmesi Üzerinde Bir Araştırma. Ankara Üniversitesi, Fen Bilimleri Enstitüsü, Peyzaj Mimarlığı Anabilim Dalı, Yüksek Lisans Tezi, Ankara.

AYTAŞ, İ. (2017). Çankırı Kentsel Açık-Yeşil Alan Sisteminin Belirlenmesi. Çankırı Karatekin Üniversitesi, Fen Bilimleri Enstitüsü, Orman Mühendisliği Anabilim Dalı, Yüksek Lisans Tezi, Çankırı.

BROWN, G., SCHEBELLA, M.F. and WEBER, D. (2014). Using Participatory GIS To Measure Physical Activity and Urban Park Benefits. Landscape and Urban Planning, 121:34-44.

ÇAY, R. ve KARAKAYA AYTIN, B. (2020). Kentsel Açık ve Yeşil Alan Varlığının Eski ve Yeni Yerleşim Bölgeleri Üzerinden Okunması: Edirne Örneği. Uluslararası Sosyal Bilimler Akademi Dergisi, (4):1084-1102.

DOYGUN, H. ve İLTER, A.A. (2007). Kahramanmaraş Kentinde Mevcut ve Öngörülen Aktif Yeşil Alan Yeterliliğinin İncelenmesi. Ekoloji Dergisi, 16(65):21-22.

DURMUŞ, S. (1997). Peyzaj Planlamada Proje ve Uygulama Tekniğinin Gelişimi Üzerine Bir Araştırma. Ankara Üniversitesi, Fen Bilimleri Enstitüsü, Peyzaj Mimarlığı Anabilim Dalı, Yüksek Lisans Tezi, Ankara.

EŞBAH, H. (2006). Aydın'da Kent Parklarının Bazı Ekolojik Kalite Kriterleri Yönünden İrdelenmesi. Ekoloji, 58:4248.

ETLİ, B. (2002). Edirne İli Merkez İlçe Yeşil Alan Sisteminin Peyzaj Mimarlığ İlkeleri Yönünden İrdelenmesi. Trakya Üniversitesi Bilimsel Araştırmalar Dergisi B Serisi Fen Bilimleri, 3(1):47-59.

GOLD, S.M. (1980). Recreation Planning and Design. McGraw-Hill Book Company, 322 pp., New York.

GÜL, A. ve KÜÇÜK, V. (2001). Kentsel Açık-Yeşil Alanlar ve Isparta Kenti Örneğinde İrdelenmesi. Süleyman Demirel Üniversitesi Orman Fakültesi Dergisi, 2(1):27-48.

HILMERSEIMER, H. (1955). The Nature of Cities: Origin, Growth, and Decline; Pattern and Form; Planning Problems. Paul Theobald \& Co., 286 pp., Chicago, USA.

KELOĞLU, E. ve KARABACAK, K. (2020). Ankara İli Keçiören İlçesi'nde Açık Yeşil Alanlarının Değerlendirilmesi. Ankara Üniversitesi Dil ve Tarih-Coğrafya Fakültesi Dergisi, 60(2):776-802.

KİZİROĞLU, A.M. (2017). Türkiye'nin Nüfus Değişimine Göre İl Bazında Kentleşmesine Bir Bakış (1965-2014). Karadeniz Sosyal Bilimler Dergisi, 9(16), 153-183.

KOÇ, B. (2019). Giresun Kent Merkezindeki Açık Yeşil Alan Durumunun İrdelenmesi. Ordu Üniversitesi, Fen Bilimleri Enstitüsü, Peyzaj Mimarlığı Anabilim Dalı, Yüksek Lisans Tezi, Ordu.

KOÇAN, N. ve İBİŞ, Ş. (2020). Çankırı İli Kentsel Açık Yeşil Alan Varlığının Belirlenmesi ve Geliştirilmesi Üzerine Bir Araştırma. Ordu Üniversitesi Bilim ve Teknoloji Dergisi, 10(2):154-163.

KUTER, N. (2007). Çankırı Kenti Açık ve Yeşil Alan Varlığı İçinde Tarihi Kent Merkezinin Kentsel Peyzaj Tasarımı Açısından Değerlendirilmesi. Ankara Üniversitesi, Fen Bilimleri Enstitüsü, Peyzaj Mimarlı̆̆ı Anabilim Dalı, Doktora Tezi, Ankara. 
MENTEŞE, S. (2019). Bilecik Şehir Merkezinde Kentsel Açık-Yeşil Alanların Değerlendirilmesi. Uluslararası Sosyal ve Beşerî Bilimler Araştırma Dergisi, 6(33):373-379.

PAMAY, B. (1978). Kentsel peyzaj planlaması. İ.Ü. Orman Fakültesi Yayınları, No: 2487-265, 95 sy, İstanbul.

ROMAGOSA, F. (2018). Physical Health in Green Spaces: Visitors' Perceptions And Activities in Protected Areas Around Barcelona. Journal Of Outdoor Recreation And Tourism, 23:26-32.

T.C. SAĞLIK BAKANLIĞI (2011). Fiziksel Aktivite. T.C. Sağlık Bakanlığı Halk Sağlı̆̆g Genel Müdürlüğü Sağlıklı Beslenme ve Hareketli Hayat Dairesi Başkanlığı. https://hsgm.saglik.gov.tr/tr/fiziksel-aktivite/ulkemizdedurum.html\#: :text=Sa\%C4\%9F1\%C4\%B1k\%20Bakanl\%C4\%B1\%C4\%9F\%C4\%B1\%20taraf\%C4\%B1ndan $\% 202011$ 'de,ciddi\%20boyutlarda\%20oldu\%C4\%9Funu\%20ortaya\%20koymaktad\%C4\%B1r. (Erişim Tarihi: $01.05 .2021)$

TÜIK (2020). Türkiye İstatistik Kurumu, Adrese Dayalı Nüfus Kayıt Sistemi. https://data.tuik.gov.tr/Bulten/Index?p=Adrese-Dayali-Nufus-Kayit-Sistemi-Sonuclari-2020-37210 (Erişim Tarihi: 15.12.2020)

YAVUZ, A. ve EMINAĞAOĞLU, Z. (2007). Artvin Kentinde Yeşil Alanların Yeterlilik Bakımından İrdelenmesi. TMMOB Harita ve Kadastro Mühendisleri Odası Ulusal Coğrafi Bilgi Sistemleri Kongresi, KTÜ, Trabzon.

YAZICI, K. ve GÜLGÜN ASLAN, B. (2017). Açık-Yeşil Alanlarda Dış Mekân Süs Bitkilerinin Önemi ve Yaşam Kalitesine Etkisi; Tokat Kenti Örneği. Ege Üniversitesi Ziraat Fakültesi Dergisi, 54(3):275-284.

YAZICI, K. ve ÜNSAL, T. (2019). Kentsel Yaşam Kalitesi Açısından Süs Bitkilerinin Önemi; Tokat/MerkezYeşilırmak Örneği. Ziraat Mühendisliği, (367), 66-76.

YÜCESU, Ö., KORKUT, A. ve KIPER, T. (2017). Kırklareli Kent Merkezinin Açık ve Yeşil Alanların Analizi ve Bir Sistem Önerisi. Artium, 5(2):22-37. 